\title{
PENGARUH SIKAP DAN NORMA SUBJEKTIF TERHADAP INTENSITAS PENGGUNAAN APLIKASI STREAMING PADA GENERASI "Z"
}

\author{
Endhar Priyo Utomo ${ }^{1}$, Nadia Probosini ${ }^{*}$ \\ ${ }^{1}$ Universitas Diponegoro, Indonesia \\ *e-mail: nadiaprobosini@gmail.com
}

\begin{abstract}
Abstrak
Tujuan penelitian ini adalah untuk mengetahui pengaruh sikap dan norma subyektif yang menyangkut persepsi masyarakat gen $\mathbf{Z}$ terhadap tingkat intensi seseorang dalam menggunakan aplikasi musik streaming. Penelitian ini hanya berfokus pada penggunaan Spotify dan Joox karena kedua aplikasi tersebut lebih umum digunakan oleh masyarakat Indonesia. Penelitian ini dilaksanakan di kota Semarang dengan data yang diperoleh dengan menyebarkan kuesioner pada masyarakat gen Z di Semarang menggunakan skala Likert (1-5) dan diproses menggunakan SPSS 22.0. Hasil dari penelitian ini menunjukkan bahwa: (i) terdapat pengaruh antara sikap gen $Z$ terhadap intensi penggunaan streaming musik dengan nilai t-hitung sebesar 9,884 dan tingkat signifikansi 0,000 , (ii) terdapat pengaruh antara norma subjektif terhadap intensi penggunaan streaming musik dengan nilai t-hitung sebesar 3,321 dan tingkat signifikan 0,001 , (iii) terdapat pengaruh antara sikap dan norma subjektif terhadap intensi penggunaan streaming musik dengan nilai $F$ hitung sebesar 68,269 dan tingkat signifikan 0,000 . Penelitian ini menunjukkan hubungan antara masyarakat generasi Z dengan penggunaan media digital serta mengetahui bagaimana pola konsumsi mereka berdasarkan pengaruh dari lingkungan sekitarnya. Sedangkan hasil penelitian ini akan berguna sebagai referensi perkembangan strategi bisnis industri musik kedepannya.
\end{abstract}

Kata kunci: Sikap; Norma Subjektif; Generasi Z

\begin{abstract}
The study examines the effects on the attitude and subjective norms related to the $Z$ generation's community's perception of someone's intention to use streaming music application. This study only focuses on using Spotify and Joox because the teenagers in Indonesia more commonly use both applications. This research was conducted in Semarang City with data obtained by distributing questionnaires to the generation Z community in Semarang using a Likert scale (1-5) and processed using SPSS 22.0. The results of this study indicate that: (i) there is an influence between the attitude of the $Z$ generation and the intention to use music streaming with a t-test value of 9,884 and a significance level of 0,000 , (ii) there is an influence between subjective norms and the intention to use music streaming with the value of t-count 3,321 and a significant level of 0,001 , (iii) there is influence between attitudes and subjective norms on the intention to use music streaming with a calculated $F$ value of 68,269 and a significant level of 0,000 . This study shows the relationship between the $Z$ generation and the use of digital media and finds out how their consumption patterns are based on the surrounding environment's influence. This study will be useful as a reference for the development of the business strategy of the music industry in the future.
\end{abstract}

Keywords: Attitude; Subjektif Norm; Z Generation 


\section{PENDAHULUAN}

Beberapa dasawarsa terakhir ini telah terjadi perkembangan teknologi dan informasi yang sedemikian pesat. Perkembangan yang sedemikian pesat ini telah memberikan banyak perubahan dalam berbagai aspek kehidupan. Perkembangan teknologi informasi juga telah mengubah perilaku sebagian masyarakat dalam kehidupannya. Munculnya teknologi internet adalah sebagai bentuk dari perkembangan teknologi informasi dan komunikasi.

Berdasarkan hasil studi Polling Indonesia yang berkerjasama dengan Asosiasi Penyelenggara Jasa Internet Indonesia (APJII) disebutkan bahwa saat ini jumlah pengguna internet yang ada di Indonesia telah mencapai 171,17 juta jiwa atau sekitar 64.8 persen dari jumlah populasi penduduk Indonesia. Angka ini menunjukkan terjadinya peningkatan penetrasi pengguna internet di Indonesia sebanyak 10,12 persen dari data di tahun sebelumnya.

Tingginya tingkat penetrasi internet yang ada di Indonesia, memberikan dampak kepada industri musik di Indonesia. Pola konsumsi sebagian masyarakat mengalami banyak pergeseran dalam menikmati musik saat ini.Sebelum adanya teknologi internet merambah industri musik di Indonesia, sebagian masyarakat masih menggunakan perangkat radio dan kepingan $C D$ untuk menikmati alunan musik yang digemarinya. Perkembangan internet dan teknologi informasi yang sangat pesat, menjadikan sebagian orang lebih memilih untuk menggunakan musik digital dibandingkan menggunakan media musik fisik seperti CD dan kaset (Ajzen, 2005).

Hadirnya Digital Music Streaming
Service sebagai salah satu bagian
perkembangan teknologi di bidang perkembangan teknologi di bidang sebagian masyarakat penggemar dan penikmat musik untuk menikmati alunan musik dimana saja dan kapan saja tanpa ada batasan. Hal ini sangat berbeda dengan keadaan pada masa sebelum hadirnya Digital Music Streaming Service (DMSS), yang mana penggemar dan penikmat musik hanya bisa mendengarkan alunan musik melalui media radio atau melalui kepingan-kepingan $C D$ yang bisa diperoleh secara bebas. Pengguna DMSS ini dapat membuat playlist serta memilih genre musik yang diinginkannya. Layanan berbasis format digital ini dapat diakses melalui smartphone sehingga pengguna tidak perlu lagi membawa pemutar $C D$ atau kaset seperti pengalaman di era sebelumnya. Kemudahan dalam mengakses musik streaming melalui fasilitas yang ada di smartphone juga diimbangi dengan tingkat pertumbuhan pengguna smartphone yang pada tahun 2017 telah tercatat sebanyak 62,69 juta jiwa di Indonesia, hal ini tentunya secara langsung berimbas pada pertumbuhan pengguna layanan streaming musik. Disebutkan dalam sebuah survei yang dilakukan oleh Asosiasi Penyelenggara Jasa Internet Indonesia (APJII) bahwa 35,5 persen dari populasi pengguna internet di Indonesia, atau sekitar 46,9 juta orang Indonesia mendengarkan musik secara online.

Dalam perkembangannya, saat ini pengguna layanan streaming berkembang sedemikian pesat, Salah satunya adalah pengguna layanan streaming Spotify. Utomo (2017) mengungkapkan bahwa jumlah pengguna Spotify di beberapa belahan dunia meningkat tajam dari 100 juta pengguna pada tahun 2016 menjadi 140 juta pada awal tahun 2017. Data lain yang dikeluarkan oleh Nielsen juga menyebutkan bahwa pengguna streaming dari tahun 2015 hanya 32 persen dan meningkat pada tahun 2017 sebanyak 41 persen. Di Indonesia sendiri menurut survei yang dilakukan oleh daily social pada tahun 2018 mengatakan bahwa sebanyak 88 persen orang mendengarkan musik melalui fasilitas layanan streaming (Wahyuni, 2018). Bertambahnya jumlah pengguna layanan musik streaming ini juga didukung oleh beberapa provider yang menawarkan layanan DMSS sebagai salah satu bagian bonus dari pembelian internet, hal ini tentunya akan semakin mempernudah untuk menikmati layanan musik streaming (Utomo, 2017). Dalam salah satu survei yang dilakukan oleh perusahaan telekomunikasi nasional disebutkan bahwa 90 persen dari 17 juta penggunanya telah menggunakan layanan musik streaming .

$\mathrm{Di}$ Indonesia sendiri saat ini setidaknya tersedia beberapa penyedia layanan music streaming yang cukup dikenal. Diantaranya adalah Joox, Spotify, Aple Music dan SoundCloud. Berdasarkan hasil survei dari DailySocial yang berkerjasama dengan JakPat Mobile Survey Platform kepada 1955 responden yang tersebar di seluruh Indonesia disebutkan bahwa 85 persen responden menyatakan bahwa mereka mendengar 
streaming musik online secara reguler dalam enam bulan terakhir ini. Dalam data tersebut dapat diketahui bahwa betapa tingginya minat dari sebagian besar penikmat musik untuk mendengar alunan musik melalui layanan streaming musik. Data lain yang juga menarik adalah sebagian besar pengguna layanan streaming adalah orang-orang yang termasuk dalam kategori generasi millenia atau dikenal dengan nama generasi " $Z$ ", sebuah generasi yang berada dalam rentang usia 16 hingga 24 tahun (Wahyuni, 2018). Dalam sebuah hasil survei yang dilakukan oleh salah satu penyedia aplikasi layanan streaming. Joox disebutkan bahwa rata-rata setiap pengguna menghabiskan waktu rata-rata selama 72 menit tiap harinya untuk menikmati layanan streaming musik.

Definisi generasi menurut (Ajzen, 1991) mengatakan bahwa generasi adalah sekelompok individu yang mengidentifikasi kelompoknya berdasarkan kesamaan tahun kelahiran, umur, lokasi, dan kejadiankejadian dalam kehidupan kelompok individu tersebut yang memiliki pengaruh signifikan dalam fase pertumbuhan mereka. Generasi $Z$ adalah mereka mampu mengaplikasikan semua kegiatan dalam satu waktu (multitasking) seperti menjalankan sosial media menggunakan ponsel, browsing menggunakan $\mathrm{PC}$, dan mendengarkan musik menggunakan headset. Apapun yang dilakukan kebanyakan berhubungan dengan dunia maya. Sejak kecil generasi ini sudah mengenal teknologi dan akrab dengan gadget canggih yang secara tidak langsung berpengaruh terhadap kepribadian Pembagian generasi tersebut juga banyak dikemukakan oleh peneliti-peneliti lain dengan label yang berbeda-beda, tetapi secara umum memiliki makna yang sama. Sebagai contoh menurut Martin \& Tulgan Generasi $Y$ adalah generasi yang lahir pada kisaran tahun 1978, sementara menurut Howe \& Strauss generasi $Y$ adalah generasi yang lahir pada tahun 1982, hal tersebut terjadi karena adanya perbedaan skema yang digunakan untuk mengelompokkan generasi tersebut, karena peneliti-peneliti tersebut berasal dari Negara yang berbeda (Putra, 2016). Disini penulis akan menganut pembagian generasi berdasarkan penelitian Schiffman \& Kanuk (2007) yang menunjukkan masuknya Generasi Z didalam kelompok generasi, yang dapat dilihat dalam tabel berikut:

Tabel 1. Perbedaan Generasi

\begin{tabular}{cc}
\hline Tahun Kelahiran & Nama Generasi \\
\hline $1925-1946$ & Veteran generation \\
\hline $1946-1960$ & Baby boom generation \\
\hline $1960-1980$ & $X$ generation \\
\hline $1980-1995$ & $Y$ generation \\
\hline $1995-2010$ & $Z$ generation \\
\hline $2010+$ & Alfa generation
\end{tabular}

Kelompok generasi $Z$ adalah mereka yang lahir pada tahun 1995-2010 karena di Indonesia sendiri, internet pertama kali muncul pada tahun 1990 dan mulai beredar digunakan oleh masyarakat pada tahun 1994. Maka dari itu, generasi Z pertama di Indonesia adalah mereka yang lahir pada pertengahan tahun 1990 sampai pertengahan 2000. Berakar dari perubahan perilaku generasi $Z$ dalam penggunaan teknologi tersebut secara langsung akan berdampak signifikan terhadap industri musik, dimana rekaman musik digital semakin berkembang dan para musisi mulai melebarkan pasar promosi melalui media digital seperti Youtube, media sosial, digital music streaming services dan lain sebagainya.
Secara umum, kehadiran musik streaming di ranah masyarakat khususnya generasi $Z$ ini memberikan beberapa keuntungan seperii memudahkan mereka dalam mendengarkan musik dimanapun dan kapanpun, kebebasan pengguna dalam mencari lagu apapun dengan satu kali klik pencarian di satu aplikasi tanpa perlu susah mencari, menghemat memori handphone, legalitas terjamin, tersedia lirik lagu, dan jauh dari virus-virus berbahaya. Tidak hanya itu, pengguna musik streaming ini bisa menggunakan banyak perangkat dalam satu akun seperti PC, tablet, HP dan perangkat music player lainnya.Meski begitu, aplikasi musik ini ada yang bisa didengarkan secara cuma-cuma dan ada pula yang berbayar. Apabila pengguna 
mendengarkan lagu secara gratis, biasanya mereka akan sering menemui iklan, tetapi apabila pengguna setuju untuk membayar maka mereka sudah memberi dukungan atas hak cipta dari lagu yang didengarkan.

Tujuan penelitian ini adalah untuk mengetahui pengaruh sikap dan norma subyektif yang menyangkut persepsi masyarakat generasi $Z$ terhadap tingkat intensi seseorang dalam menggunakan aplikasi musik streaming. Munculnya aplikasi musik streaming secara terangterangan mengubah sikap masyarakat generasi $Z$ dalam mengkonsumsi musik melalui musik streaming, alasan dasar utamanya tidak lain karena memberikan kemudahan masyarakat dalam mendengarkan musik. Meski begitu, hal ini juga tidak bisa terlepas dari norma subyektif masyarakat. Menurut Arta (2012) norma subjektif ternbetuk karena adanya keyakinan normatif dan motivasi dari referen yang dipercayai oleh konsumen. Penilaian terhadap norma subjektif dimaksudkan untuk mengetahui apakah lingkungan sosial mempengaruhi perilaku konsumen.

Pada penelitian terdahulu Naratama (2016) mengaplikasikan teori reasoned action (TRA) dalam menjelaskan niat beli produk hijau di kota Denpasar. Dengan menggunakan analisis regresi linear, hasil dalam penelitian ini menunjukkan bahwa pengetahuan tentang lingkungan berpengaruh positif terhadap Sikap pada lingkungan, sikap pada lingkungan berpengaruh positif terhadap Niat beli produk hijau dan Norma subjektif berpengaruh positif terhadap Niat beli produk hijau di Kota Denpasar. Kemudian penelitian lainnya dilakukan oleh Raharjo \& Japarianto (2016) yang menganalisis pengaruh dari experience ketika menggunakan DMSS yang akan berpengaruh terhadap penerimaan teknologi dan membentuk perilaku pengguna. Data yang diperoleh penelitian itu dengan menyebarkan kuisioner di Surabaya menggunakan skala likert (1-5) dan diproses menggunakan Smart-PLS.

Perbedaan penelitian ini dengan penelitian-penelitian sebelumnya terletak pada tujuan dan objek penelitian. Penelitian ini berfokus untuk mengetahui tingkat intensi seseorang dalam menggunakan aplikasi musik streaming yang didasari oleh faktor sikap pada perilaku dan norma subjektif. Penulis ingin menunjukkan hubungan antara masyarakat generasi Z dengan penggunaan media digital serta mengetahui bagaimana pola konsumsi mereka berdasarkan pengaruh dari lingkungan sekitarnya. Sedangkan hasil penelitian ini akan berguna sebagai referensi perkembangan strategi bisnis industri musik kedepannya. Penelitian ini akan mengambil sampel masyarakat generasi $Z$ di Kota Semarang untuk menggambarkan pola perilaku masyarakat secara umum terhadap penggunaan aplikasi Streaming Musik. Generasi Z sendiri merupakan generasi yang sudah terbiasa dengan teknologi informasi, internet dan berbagai aplikasi digital sejak dini. Generasi Z adalah mereka mampu mengaplikasikan semua kegiatan dalam satu waktu (multitasking) seperti menjalankan sosial media menggunakan ponsel, browsing menggunakan PC, dan mendengarkan musik menggunakan headset.

Dalam penelitian ini memiliki hipotesis diantaranya yaitu adanya pengaruh positif antara sikap gen Z terhadap intensi penggunaan streaming musik $(\mathrm{H} 1)$, adanya pengaruh positif antara norma subjektif terhadap intensi penggunaan streaming musik $(\mathrm{H} 2)$, dan adanya pengaruh positif antara sikap dan norma subjektif gen $\mathbf{Z}$ terhadap intensi penggunaan streaming musik $(\mathrm{H} 3)$

\section{METODE}

Penelitian ini termasuk penelitian kuantitatif deskriptif analisis. Menurut Sugiyono (2014), penelitian asosiatif adalah penelitian dengan tujuan untuk mengetahui hubungan antara dua variabel atau lebih. Sedangkan penelitian ini membahas dan menguji hubungan antara beberapa variabel yaitu sikap, norma subjektif, dan intensi penggunaan aplikasi streaming musik. pengetahuan tentang lingkungan,

Populasi dalam penelitian ini adalah masyarakat generasi $Z$ di Semarang. Sampel penelitian ditentukan dengan caranon probability sampling. Penarikan sampel dilakukan secara Accidental Sampling sebanyak 100 responden. Sampel adalah sebagian atau wakil dari populasi yang diteliti, dimaksudkan untuk menggeneralisasikan hasil penelitian sampel (Arikunto, 2006). Formulasi dasar dalam menentukan ukuran sampel adalah mengasumsikan bahwa populasi adalah tidak terbatas. Jadi, mengambil 100 sampel dari 5000 populasi sama dengan 100 sampel dari 200 juta populasi (Cooper \& Emory, 1998). 
Data dianalisis secara statistik menggunakan uji regresi linier berganda dalam SPSS 22.0 dengan skala Likert sebagai instrument penelitiannya. Analisis tersebut dilakukan untuk mengetahui pengaruh sikap terhadap tingkat intensi penggunaan media streaming musik, pengaruh norma subyektif terhadap tingkat intensi penggunaan media streaming musik, serta pengaruh sikap dan norma subyektif terhadap intensi penggunaan media streaming musik. Sebelum melakukan analisis regresi berganda terlebih dahulu dilakukan uji validitas, uji reliabilitas, uji statistika deskripsi dan uji asumsi klasik (Uji normalitas, uji multikolinearitas dan uji

\section{HASIL DAN PEMBAHASAN}

\section{Deskripsi Responden}

Tabel 2. Jenis Kelamin

\begin{tabular}{ccc}
\hline Jenis Kelamin & Jumlah & Prosentase \\
\hline Laki-laki & 44 & $44 \%$ \\
\hline Perempuan & 56 & $56 \%$ \\
\hline Total & 100 & $100 \%$ \\
\hline
\end{tabular}

Tabel 2 memperlihatkan didominasi oleh perempuan dengan jumlah 12 responden lebih banyak daripada laki-laki. Perbedaan tersebut dapat disimpulkan bahwa rasa suka pada musik baik untuk laki-laki maupun perempuan hampir sama baiknya. Dominasi nilai tersebut bisa juga disebabkan oleh naluri wanita yang cenderung lebih sensitif dan mudah tersentuh dalam alunan musik daripada laki-laki. Selain itu, Ajzen \& Fishbein (1977) dalam penelitiannya juga menemukan bahwa perempuan memiliki trial intention yang lebih tinggi dibandingkan laki-laki. Perempuan memiliki intensi yang tinggi ketika memutuskan untuk mencoba layanan yang berbasis teknologi dengan pengaruh kuat dari trial attitude.

Tabel 3. Usia

\begin{tabular}{ccc}
\hline Usia & Jumlah & Prosentase \\
\hline 18 & 11 & $11 \%$ \\
\hline 19 & 4 & $4 \%$ \\
\hline 20 & 17 & $17 \%$ \\
\hline 21 & 27 & $27 \%$ \\
\hline 22 & 20 & $20 \%$ \\
\hline 23 & 11 & $11 \%$ \\
\hline 24 & 10 & $10 \%$ \\
\hline Total & 100 & $100 \%$
\end{tabular}

Tabel 3 menunjukkan bahwa responden disini merupakan generasi $Z$ karena kisaran usia mereka antara 18-25 tahun atau sekitar kelahiran tahun 1995-
2010. Generasi ini termasuk generasi yang sudah terbiasa atau bahkan sudah memiliki hubungan khusus terhadap teknologi sejak dini.

Tabel 4. Pendidikan Terakhir

\begin{tabular}{ccc}
\hline Pendidikan Terakhir & Jumlah & Prosentase \\
\hline SMA/SMK/MA & 61 & $61 \%$ \\
\hline Diploma & 7 & $7 \%$ \\
\hline S1 & 33 & $33 \%$ \\
\hline Total & 100 & $100 \%$ \\
\hline
\end{tabular}

Tabel 4 menunjukkan bahwa responden yang ada di dominasi oleh mereka yang memiliki pendidikan terakhir SMA. Hal ini dapat dikaitkan dengan usia mereka mengingat responden adalah generasi $Z$ yang mayoritas sudah lulus SMA dan sedang melanjutkan studi S1 maupun baru bekerja.

Tabel 5. Frekuensi Mendengarkan per Hari

\begin{tabular}{ccc}
\hline Frekuensi Mendengarkan & Jumlah & Prosentase \\
\hline$<1$ jam & 21 & $21 \%$ \\
\hline $1-3$ jam & 56 & $56 \%$ \\
\hline$>3$ jam & 23 & $23 \%$ \\
\hline Total & 100 & $100 \%$ \\
\hline
\end{tabular}


Tabel 5 menunjukkan bahwa data responden sesuai dengan harapan karena responden menyukai musik dan rata-rata mendengarkan musik sekitar $1-3$ jam di setiap harinya sebanyak 56 persen dan lebih dari 3 jam sebanyak 23 persen.

Tabel 6. Media dalam Mengakses Streaming Musik

\begin{tabular}{ccc}
\hline Media yang digunakan & Jumlah & Prosentase \\
\hline Smartphone & 93 & $93 \%$ \\
\hline PC & 6 & $6 \%$ \\
\hline Tablet & 1 & $1 \%$ \\
\hline Total & 100 & $100 \%$
\end{tabular}

Tabel 6 menunjukkan bahwa responden menggunakan media smartphone dalam mengakses aplikasi streaming musik sebanyak 93 persen, hal ini tentu saja dipengaruhi oleh kebiasaan para generasi $Z$ yang sudah terbiasa dengan penggunaan gadget sejak dini maka dari itu mereka lebih suka mengakses di smartphone yang cenderung lebih mudah dibawa kemana saja dan mendengarkan musik dalam momen apapun.

Tabel 7. Jenis Streaming Musik

\begin{tabular}{ccc}
\hline Jenis Streaming Musik & Jumlah & Prosentase \\
\hline JOOX & 22 & $22 \%$ \\
\hline Spotify & 56 & $56 \%$ \\
\hline Joox \& Spotify & 22 & $22 \%$ \\
\hline Total & 100 & $100 \%$
\end{tabular}

Tabel 7 menunjukkan bahwa responden lebih banyak menggunakan Spotify sebanyak $56 \%$ dibandingkan dengan pengguna Joox 22 persen, kemudian sebagian lagi memiliki mendengarkan keduanya supaya mendapat manfaat lebih dari masingmasing aplikasi sebanyak 22 persen

Tabel 8. Pengeluaran untuk Berlangganan per Bulan

\begin{tabular}{ccc}
\hline Pengeluaran untuk Berlangganan & Jumlah & Prosentase \\
\hline$<50.000$ & 75 & $75 \%$ \\
\hline $50.000-100.000$ & 22 & $22 \%$ \\
\hline $100.000-150.000$ & 2 & $2 \%$ \\
\hline $150.000-200.000$ & 1 & $1 \%$ \\
\hline$>200.000$ & 0 & $0 \%$ \\
\hline Total & 100 & $100 \%$ \\
\hline
\end{tabular}

Tabel 8 menunjukkan bahwa responden kebanyakan tidak berlangganan media streaming musik sebanyak 75 persen meski ditabel 5 menunjukkan responden cukup intens dalam mendengarkan musik per harinya. 


\section{Uji Validitas}

Tabel 9. Hasil Uji Validitas

\begin{tabular}{|c|c|c|}
\hline Item Pertanyaan & R hitung & Ket. \\
\hline Saya mencari informasi terkait streaming music terbaru dan fasilitas yang ditawarkan & 0.504 & Valid \\
\hline $\begin{array}{l}\text { Saya akan menggunakan layanan streaming music untuk mendengarkan berbagai } \\
\text { macam jenis lagu mulai dari yang lama hingga terbaru. }\end{array}$ & 0,793 & Valid \\
\hline $\begin{array}{l}\text { Saya menggunakan streaming music untuk mencari lagu-lagu terbaru yang tengah } \\
\text { hangat dibicarakan. }\end{array}$ & 0,740 & Valid \\
\hline $\begin{array}{l}\text { Saya menggunakan streaming music untuk mencari lagu-lagu dari artis yang saya } \\
\text { sukai }\end{array}$ & 0,734 & Valid \\
\hline $\begin{array}{l}\text { Saya meluangkan waktu setiap hari untuk mendengarkan lagu apa saja yang terbaru } \\
\text { atau ditawarkan di halaman awal streaming music }\end{array}$ & 0,589 & Valid \\
\hline $\begin{array}{l}\text { Saya meluangkan waktu setiap hari selama lebih dari satu jam untuk mendengarkan } \\
\text { lagu yang saya sukai di streaming music }\end{array}$ & 0,754 & Valid \\
\hline $\begin{array}{l}\text { Saya mendownload lagu-lagu tertentu di streaming music untuk mendengarkan ulang } \\
\text { lagu yang saya sukai kapanpun dan dimana pun }\end{array}$ & 0,506 & Valid \\
\hline $\begin{array}{l}\text { Saya menggunakan streaming music karena mendapatkan fasilitas dan keuntungan } \\
\text { dari provider internet yang saya gunakan }\end{array}$ & 0,574 & Valid \\
\hline $\begin{array}{l}\text { Saya berlangganan di streaming music yang saya gunakan untuk mendapatkan } \\
\text { fasilitas penuh }\end{array}$ & 0,645 & Valid \\
\hline $\begin{array}{l}\text { Saya merekomendasikan streaming music yang saya gunakan pada teman-teman } \\
\text { terdekat dan orang lain }\end{array}$ & 0,607 & Valid \\
\hline
\end{tabular}

Indikator dikatakan valid apabila $r$ tabel $<\mathrm{r}$ hitung. $\mathrm{R}$ tabel adalah 0,1966 yang dapat ditentukan berdasarkan tabel $r$ (koefisien korelasi sederhana) dengan rumus $\mathrm{df}=(\mathrm{n}-2)$. Berdasarkan tabel 2.8 menunjukkan bahwa $r$ tabel $<r$ hitung maka indikator di atas adalah valid.

\section{Uji Realibilitas}

Tabel 10. Hasil Uji Realibilitas

\begin{tabular}{ccl}
\hline Item & $\begin{array}{c}\text { Cronbach's } \\
\text { Alpha }\end{array}$ & Keterangan \\
\hline Niat & 0,834 & Reliable \\
\hline Sikap & 0,875 & Reliable \\
\hline $\begin{array}{c}\text { Norma } \\
\text { Subjektif }\end{array}$ & 0,864 & Reliable \\
\hline
\end{tabular}

Uji Reliabilitas dilakukan untuk menguji konsistensi jawaban dari responden. Dikatakan reliabel apabila nilai koefisien cronbach's alpha $>0,60$ yang pada nilai tersebut merupakan nilai reliabilitas tes secara keseluruhan (Ghozali, 2006). Pada tabel diatas semua variabel memiliki koefisien cronbach alpha $>0,60$.

\section{Uji Asumsi Klasik}

Uji Normalitas

Uji normalitas bertujuan untuk menguji pada regresi berganda, dengan cara mendeteksi variabel pengganggu atau residual memiliki distribusi normal atau tidak. Pada Asymp. Sig. (2tailed) menunjukkan > 0,05 maka pola distribusi normal, dan regresi berganda memenuhi asumsi normalitas (Ghozali, 2006). Berdasarkan hasil uji nilai kolmogrov diatas, nilai Asymp. Sig. (2-tailed) sebesar 0,2> 0,05 sehingga data dikatakan normal dan memenuhi asumsi normalitas.

Uji Multikolinearitas

Uji multikolonieritas bertujuan untuk menguji pada regresi berganda apabila ditemukan adanya korelasi antar variabel bebas menunjukkan bahwa nilai tolerance untuk sikap dan norma subyektif masingmasing sebesar 0,927 dan nilai VIF masing-masing sebesar 1,079 serta pada nilai koefisien korelasi antar variabel sikap dan norma subyektif menunjukkan korelasi cukup rendah yaitu sebesar 0,271 . Apabila pada variabel memiliki nilai tolerance $<0,1$ 
dan nilai VIF $>10$ serta nilai koefisien korelasi > 0,8 dikatakan terjadi multikolinearitas (Ghozali, 2006).

Uji Heteroskedastisitas

Uji heteroskedastisitas bertujuan untuk menguji pada regresi berganda apabila terjadi ketidaksamaan variance dari residual satu pengamatan ke pengamatan yang lain. Apabila nilai signifikan < 0,05maka dikatakanterjadi heteroskedastisitas (Ghozali, 2006). Diperoleh pada tabel dibawah ini nilai signifikan pada sikap $0,234>0,05$ dan pada norma subyektif $0,664>0,05$. Maka dikatakan tidak terjadi heteroskedastisita.

\section{Uji Hipotesis}

Analisa koefisiensi determinasi (R2) untuk mengukur kemampuan model dalam menerangkan variasi variabel dependen (Ghozali, 2006). Dari analisa koefisien determinasi didapatkan nilai Adjusted $\mathrm{R}$ Square sebesar 0,576 atau sebesar $57,6 \%$. $\mathrm{Hal}$ ini dapat diartikan bahwa sebanyak $57,6 \%$ tingkat intensi generasi $Z$ dalam menggunakan media streaming musik dapat dijelaskan oleh sikap (X1) dan norma subjektif (X2) generasi Z, sedangkan sisanya sebesar $42,4 \% \quad(100 \%-57,6 \%=$ $42,4 \%$ ) dijelaskan oleh sebab-sebab yang ada di luar model penelitian ini.

\section{Uji F}

Uji F digunakan untuk menunjukkan semua variabel independen yang dimasukkan ke dalam regresi mempunyai pengaruh secara bersama-sama terhadap variabel dependen. Apabila signifikan $<0,05$ dianggap regresi tesebut mempunyai pengaruh secara simultan terhadap variabel dependen (Ghozali, 2006). Dari tabel diatas diperoleh hasil nilai $\mathrm{F}$ hitung sebesar 68,269 dengan signifikan 0,000 < 0,05 dapat dikatakan bahwa hipotesis $(\mathrm{H} 3)$ terbukti yakni variabel sikap dan variabel norma subyektif secara bersama-sama berpengaruh terhadap intensi penggunaan streaming musik.

\section{Uji T}

Uji $T$ digunakan untuk menunjukkan seberapa jauh pengaruh satu variabel independen (sikap dan norma subyektif) secara parsial dalam menerangkan variabel dependen (niat). Apabila signifikan thitung $<0,05$ maka dianggap regresi tesebut mempunyai pengaruh secara parsial terhadap variabel dependen. Pada tabel diatas menunjukkan bahwa masing-masing variabel independen memiliki tingkat signifikan kurang dari 0,05 . Hal ini berarti bahwa masing-masing variable independen berpengaruh secara parsial terhadap variabel dependen.

Hasil perhitungan uji T pada variabel sikap menunjukkan $t$ hitung sebesar 9,884 dengan tingkat signifikan $0,000<0,05$, maka dapat dikatakan bahwa hipotesis $(\mathrm{H} 1)$ terbukti yakni sikap secara parsial berpengaruh positif terhadap intensi penggunaan streaming musik pada gen $Z$. Pada variabel norma subyektif menghasilkan $t$ hitung sebesar 3,321 tingkat signifikan 0,001 $<0,05$, maka dapat dikatakan bahwa hipotesis $(\mathrm{H} 2)$ terbukti yakni norma subyektif secara parsial berpengaruh positif terhadap intensi penggunaan streaming musik pada gen $Z$.

\section{Pembahasan}

Hipotesis pertama dalam penelitian ini menyatakan bahwa sikap gen $Z$ berpengaruh positif terhadap intensi penggunaan streaming musik. Hasil penelitian diperoleh nilai t-hitung sebesar 9,884 lebih besar dari nilai t-tabel sebesar 0,1966 dengan tingkat signifikansi $0,000<$ 0,05 . Hal ini menunjukkan bahwa adanya pengaruh yang positif dan signifikan antara sekap gen $Z$ terhadap intensi penggunaan streaming musik. Artinya, variable sikap berperan terhadap munculnya intensi penggunaan streaming musik.Sikap dalam penelitian ini ditunjukkan dari bagaimana masyarakat menilai tentang manfaat dan keuntungan dalam menggunakan media musik streaming. Sikap dari individu ini mengarah pada perilaku yang akan 
mempengaruhi intensi penggunaan musik streaming. Dengan demikian, hipotesis yang diajukan dinyatakan diterima. Hasil ini sejalan dengan hasil penelitian Prihapsara (2017) tentang obat kumur yang menyatakan bahwa sikap konsumen berpengaruh secara parsial terhadap niat beli dengan pengaruh sikap lebih tinggi dari pengaruh norma subjektif. Sikap merupakan keyakinan individu terhadap suatu obyek. Sikap ini akan mengarah ke perilaku, yang mengukur sampai sejauh mana perilaku yakin atau tidak yakin, suka atau tidak suka. Faktor sikap disini seperti keyakinan, pengetahuan, emosional, dan tingkah laku. Semakin positif keyakinan individu akan akibat dari suatu obyek, maka akan semakin positif pula sikap individu terhadap obyek tersebut.

Hipotesis kedua dalam penelitian ini menyatakan bahwa norma subjektif berpengaruh positif terhadap intensi penggunaan streaming musik. Hasil penelitian diperoleh nilai t-hitung sebesar 3,321 lebih besar dari nilai t-tabel sebesar 0,1966 dengan tingkat signifikan 0,001 < 0,05 . Hal ini menunjukkan bahwa adanya pengaruh yang positif dan signifikan antara norma subjektif terhadap intensi penggunaan streaming musik. Artinya, variable norma subjektif berperan terhadap munculnya intensi penggunaan streaming musik. Norma subjektif ini akan mengukur pengaruh orang lain sampai sejauh mana dalam mempengaruhi keputusannya untuk menggunakan aplikasi streaming musik. Semakin dekat hubungan sosial individu maka semakin positif juga individu itu meyakini gagasan orang-orang terdekat, sehingga norma inilah yang membentuk norma subjektif dalam dirinya, yang akhirnya akan membentuk perilakunya untuk meyakini suatu objek. Dengan demikian, hipotesis yang diajukan dinyatakan diterima. Hasil ini sesuai dengan hasil penelitian terdahulu (Prihapsara, 2017) tentang obat kumur yang menjelaskan bahwa norma subjektif secara parsial berpengaruh terhadap niat beli dengan perolehan pengaruh norma sebjektif yang lebih rendah dari pengaruh sikap. Norma subjektif merupakan keyakinan konsumen terkait dengan normanorma yang berhubungan dengan objek sikap.Objek sikap disini seperti kepercayaan, pengetahuan, tingkat pendidikan, tingkat pendapatan dan lainlain.

Hipotesis ketiga dalam penelitian ini adalah sikap dan norma subjektif secara bersama-sama memiliki pengaruh positif terhadap intensi penggunaan streaming musik. Berdasarkan uji $F$ untuk variabel sikap dan norma subyektif terhadap niat beli didapat nilai $F$ hitung sebesar 68,269 dengan tingkat signifikan 0,000 $<0,05$. Maka dapat dikatakan bahwa hipotesis $(\mathrm{H} 3)$ terbukti yakni variabel sikap dan variabel norma subyektif secara simultan berpengaruh terhadap intensi penggunaan streaming musik dengan pengaruh dari keduanya. Hasil ini sesuai dengan hasil penelitian terdahulu (Prihapsara, 2017) tentang obat kumur yang menunjukkan bahwa sikap dan norma subjektif secara bersama-sama berpengaruh positif terhadap niat beli konsumen. Niat merupakan faktor motivasional yang menghubungkan diri dengan tindakan yang akan dilakukan. Niat dipandang sebagai satu variabel penentu bagi perilaku yang sesungguhnya. Sehingga niat untuk berperilaku ini akan bergantung pada sikap dan norma subyektif atas perilaku. Maka semakin kuat niat konsumen untuk melakukan pembelian, semakin besar pula keberhasilan prediksi perilaku tersebut.

\section{SIMPULAN DAN SARAN}

Berdasarkan hasil penelitian yang telah diuaraikan sebelumnya maka dapat ditarik beberapa kesimpulan. Yang pertama adalah terdapat pengaruh antara sikap gen $Z$ terhadap intensi penggunaan streaming musik. Hasil penelitian diperoleh nilai thitung sebesar 9,884 lebih besar dari nilai ttabel sebesar 0,1966 dengan tingkat signifikansi $0,000<0,05$. Dengan demikian 
hipotesis penelitian pertama diterima. Yang kedua adalah terdapat pengaruh antara norma subjektif terhadap intensi penggunaan streaming musik. Hasil penelitian diperoleh nilai t-hitung sebesar 3,321 lebih besar dari nilai t-tabel sebesar 0,1966 dengan tingkat signifikan $0,001<$ 0,05 . Dengan demikian hipotesis penelirian kedua diterima. Yang ketiga adalah terdapat pengaruh antara sikap dan norma subjektif terhadap intensi penggunaan streaming musik. Hasil uji $F$ untuk variabel sikap dan norma subyektif terhadap niat beli didapat nilai $\mathrm{F}$ hitung sebesar 68,269 dengan tingkat signifikan $0,000<0,05$. Maka dapat dikatakan bahwa hipotesis $(\mathrm{H} 3)$ terbukti yakni variabel sikap dan variabel norma subyektif secara simultan berpengaruh terhadap intensi penggunaan streaming musik dengan pengaruh dari keduanya.

\section{DAFTAR PUSTAKA}

Ajzen, I. (1991). The Theory of Planned Behavio. Organizational Behavior and Human Decision Processes, 50(2), 179-211.

Ajzen, I. (2005). Attitudes, Personality, Behavior, 2nd Edition. Open University Press.

Ajzen, I., \& Fishbein, M. (1977). Attitudebehavior relations: $A$ theoretical analysis and review of empirical research. Psychological Bulletin, 84(888918).

Arikunto, S. (2006). Prosedur Penelitian: Suatu Pendekatan Praktik Edisi Revisi Keenam. Rineka Cipta.

Arta, K. S. (2012). Kolaborasi Masyarakat Sipil, Politik dan Ekonomi dalam Pemanfaatan Modal Sosial. Jurnal IImu Sosial Dan Humaniora, 1(2), 117-128.

Cooper, D. R., \& Emory. (1998). Metode Penelitian Bisnis Edisi Kelima. Erlangga.

Naratama, M. (2016). Aplikasi Theory Reasoned Action (TRA) Dalam
Menjelaskan Niat Beli Produk Hijau di Kota Denpasar. Universitas Udayana.

Prihapsara, E. (2017). Pengaruh Sikap dan Norma Subjektif Terhadap Niat Beli Personal sebagai Konsumen Potensial Produk Obat Kumur. Universitas Sebelas Maret.

Putra, S. Y. (2016). Theoritical Review: Teori Perbedaan Generasi. Stie AMA.

Raharjo, S., \& Japarianto, E. (2016). Pengaruh User Experience Terhadap Behavior Intention to Use Digital Music Streaming Services dengan Attitude Toward Behavior Sebagai Media Intervening. Universitas Kristen Petra.

Schiffman, L. G., \& Kanuk, L. L. (2007). Consumer Behavior (Ninth Edit). Pearson Prentice Hall.

Sugiyono. (2014). Metode Penelitian Kuantitatif, Kualitatif, dan $R \& D$. Alfabeta.

Utomo, M. S. (2017). Faktor-Faktor yang Mempengaruhi Niat Konsumen untuk Membeli Kembali Musik dari Layanan Musik Streaming. Universitas Gadjah Mada.

Wahyuni, R. R. (2018). Hubungan Antara Penggunaan Aplikasi Streaming Musik Joox Dengan Kepuasan Mendengarkan Musik Pada Mahasiswa FISIP Universitas Hasanudin. Universitas Hasanudin. 